\title{
THE AMPHIOEN SOCIETY AND THE END OF THE VOC
}

Until 1745 the usual organization of the opium business in Dutch East Indies was that the colonial government/VOC imported the raw opium from Bengal (sometimes from Persia or the Levant) and leased or distributed it for further processing and selling to European, Chinese and indigenous 'farmers' through public auctions. The chests became labeled with all kinds of marks and seals to avoid fraudulent actions. The opium could be paid for in cash or on credit. The government's monopoly position concerned, therefore, the import and distribution of opium, a distribution largely confined to Batavia. Sales in Java or elsewhere in the archipelago were done by the opium farmers.

The gross profit for the VOC/government was, of course, the difference between the Bengal purchasing price and the Java auction price. It sustained this monopoly by military force throughout the realm. The costs of this had to be calculated into the net profit. Thanks to this construction, anybody (European or indigenous) trading in opium outside this framework was consequently considered as "smuggling" which "violated" this monopoly. So, every time "smuggler", "smuggling" or "illicit" is used below without these inverted commas, please be aware that it is a VOC judgment. Smugglers and other sappers of the monopoly represent the only available free opium market. It's a view seldom supported by the VOC historians even today.

The VOC morality had another side. From the introduction of opium in the 17th-century onwards, it can be assumed that VOC officials corrupted their own system by becoming involved in some private opium selling or other business. This continued, as we shall see, until the last years of the Dutch presence in the East Indies. The general attitude was this is forbidden, but it cannot be avoided; the VOC remunerations are too low, so "they" have to make an "additional, private" income. Therefore, the general practice became: manipulations of the weights, the quantities and quality of the goods, the prices, the bookkeeping, the storage, bribing producers, and so on. ${ }^{1}$

\footnotetext{
1 See F. Gaastra (1991), p. 94 ff. The OED indicates that since 1608 "Dutch" was 'used in derision and contempt', which must have some ground! There is a substantial difference
} 
The severest punishments for European smugglers and cheaters consisted only of monetary fines and confiscation or a compulsory return home. Sharing the 'silent profits' with the European VOC judges could lead to the avoidance of much of this punishment. Anyway, the barbarous death penalties suffered by non-Europeans were seldom executed on their "own kind". This made the notorious Amboyna Massacre (1623) of twenty English convicts, who undermined the VOC monopoly, so exceptional.

From the middle of the 18th-century, something very different happened. On top of all this illicit private business conducted by VOC employees stationed somewhere in the realm, the opium monopoly of the colonial state itself was bartered away, and the actors in this game were the highest officials and some 'free burghers' in both the Dutch and the colonial state. This happened through the invention of the Amphioen or Opium Society (AS; 1745-1794). As such, it seems to be the ultimate consequence of the acts of 'the robber-state along the North Sea' (Multatuli).

A contemporary of Multatuli, Governor-General Baud, was certainly not of this opinion, but he must have had a personal, bad experience with the AS phenomenon. He ironically concluded:

As could be predicted, the Amphioen Society could not fulfill its aim to bridle the smuggling effectively and to provide the Company with the advantages of a regular yearly turn-over of 1200 chests opium ... it was already difficult to arrive at 800 chests ... A remarkable group of citizens, earlier involved in the smuggling themselves, was interested in attacking the illicit import of opium. However, the number of bureaucrats and citizens, who could not become shareholders, remained large enough to be involved in smuggling ...2

And what did the inventors of the AS tell the public? In a dispatch (March 1746) to the Directors in Amsterdam, VOC-Batavia described the first experiences of this Opium Society in a frank way never repeated by current Dutch historians. This concerns the perpetual debate about the effects of the price level on opium consumption and smuggling, which persisted in the colony until 1940. The text also provides a shallow legitimation for establishing this Amphioen Society:

between the colonization and imperialism of the Dutch and the English or French: in the last two ventures the aristocratic element was much larger than in the Dutch "petty bourgeoisie" one. Only after the Netherlands became a kingdom some Dutch aristocrats (if left) could participate sometimes in the East Indies (see later NHM and Billiton). See for this important aspect J. Nederveen Pieterse, p. 193-223 and passim.

2 J. C.Baud, p. 124. 
A few merchants received in 1745 a ten-year contract [octroy] for the trade in opium, because it is impossible to keep the opium price in Batavia as high as during the auctions of the Company in June 1743 and March 1744 and because it is impossible to sell a large quantity of opium without attracting smugglers thanks to the high price. Smugglers risk their life for it, and the indigenous people like to help them if they deliver the opium for a hundred rixdollars per chest cheaper. After the arrival of the [ship the] Nieuwvliet from Bengal with only $75^{\circ}$ chests of opium, the Society had to sell the opium for 550 rixdollars per chest, meaning: 100 rixdollars per chest lower than the purchasing price from the Company ... If there is a low price, the consumption will increase and smugglers will be discouraged, because they do not want to risk their lives if the profits are too low or have to deliver opium of lower quality than that of the Company, and for a lower price which is not interesting any more. Although it looks as if the Company could get the profit of the Society itself, this is not the case, and the Society gives the Company the most profit. Even if the Society is able to pay $6 \%$ every six months, no merchant can compete with it: it is too risky an affair for a profit of $12 \%$ in a year. Too much money must be invested which has to be borrowed against a too high interest; therefore, the Society is more advantageous for the Company. The interest of the Company and of the Society is as large a market as possible for the opium, even for a lower price. The price of the shares of the Society is not fixed yet. At the moment there is already an agio of 15 to $20 \%$. Batavia expects that this can increase unto $150 \%$. The Society has all the opium which can be imported through the Strait of Malacca including that which can be captured as contraband of the first degree east of the meridian of the Prince island ... ${ }^{3}$

The relevant Dutch researchers have never reflected enough on Baud's "self-conceit" or the AS initiators' eulogy. That is a pity because what happened there foreshadowed the most important 19th-century development of the Opium Problem, discussed below in some detail.

To explain the backgrounds of this AS, it is necessary to shed some light on the inventor of this innovation. Until now, it was assumed to be the acting Governor-General, Count Van Imhoff, who certainly was highly positive about the new initiative for obvious reasons. In my reconstruction of the case, however, another person should be "credited" for it. Who is this inventor, who built a remarkable VOC career from humble seaman to Governor-General?

3 GM, XI, p. $33^{2}$. 


\section{A Brilliant Economist?}

This new key figure in the VOC opium game was Jacob Mossel (17041761). He must be considered the first drugs baron, as the first private opium dealer on a large scale. ${ }^{4}$ Some current historians see him as a very capable Governor-General together with people like his colleagues Van Hoorn, Van Imhoff and a few others. They all had to do their work among the generally corrupt elite. ${ }^{5}$ The most favorable opinion about the man is given by Blussé. According to him, Mossel, the successor of GovernorGeneral Van Imhoff, this 'viceroy', was made a scapegoat since he would have represented all evils of the ancien régime.

He has also been criticized for having made private trade impossible, but here the curious problem poses itself that Batavia underwent a period of prosperity during his reign ... It is striking how historians have parroted each other in this case. A century ago ... Mossel [was described] as the man who only wanted to leave the "trash" ... of the Company's trade to the burghers. Everybody has blindly accepted this verdict without checking it against the sources. Mossel actually was a brilliant "economist", as his contemporaries called him. He indeed forbade private trading between Batavia and the Indian subcontinent, but he was fully in favor of leaving a large share of the trade at Batavia to private entrepreneurs. ... Mossel had a good understanding of the growing commercial interest of the British ... after Mossel's death his successors again drew all trade to the Company as its general condition declined and levied high taxes which totally ruined the citizenry. ${ }^{6}$

4 For the following data see the Wikipedia biography, but also www.antenna. $\mathrm{nl} /$ fwillems/nl/nest/mossel.html and Siemen Duys extensive story of the most honorable citizen in the Enkhuizen history at the occasion of a Mossel exhibition: http://toerisme. bruist.nu. The most positive, however, is Leonard Blussé in R.Ross, G. Telkamp, ed., p. 81 ff. The latter used, among others, also an article of W. Coolhaas about Mossel, who apparently is the source of the revision à la Blussé. Same text is published by B. in his (1986), p. 31 .

5 F. Gaastra (1991), p. 97 also referred to Van Lier; in the previous and following pages he gives many examples of this general corruption. This corruption was a standard characteristic of VOC officials from the beginning. See, for instance, Both, vol. 1, p. 63 .

6 L. Blussé, in: Idem, p. 81, 82 must have known the earlier C. Boxer (1977), because the author thanks Blussé (p. 112) for sending him a photocopy. Well, Boxer, is one of the fiercest critics of Mossel and Blussé does not discuss the opinion of simply the best scholar at issue. The glorification of Van Imhoff and Mossel, of course, continues in the present official Dutch VOC propaganda, in which prime ministers urge the Dutch public to demonstrate again a VOC spirit (Balkenende, 2007)! In this spirit see also H. Stevens a publication of the Rijksmuseum, Amsterdam: the words "opium" or slavery, for instance, are never heard or used, let alone a reference to the continuous wars and massacres, except the pictures of the beautiful uniforms VOC soldiers apparently wear during their slaughter work. For a quite favorable view on Van Imhoff and Mossel see D. Hall, p. $312 \mathrm{ff}$. 
Mossel must have been a genius if we believe what Blussé writes from his "sources". ${ }^{7}$ First, the obvious mistakes in this quotation. That Mossel 'made private trade impossible' is a fundamental misunderstanding of the nature of the Amphioen Society. ${ }^{8}$ This argument will be explained further below.

Mossel should be called a clever self-made man with the rather exceptional ability in the VOC of knowing how to write, read and persuade the highest persons in favor of a most stupid plan; he is excessively motivated to make as much money as possible and to give his own person the glamor of a Sun King.

A qualification as 'brilliant economist' can only be invented by people who are not acquainted with the texts of economists, let alone the brilliant ones like those 18th-century contemporaries of Mossel like Colbert, Turgot, Quesnay, Galiani or Adam Smith, David Hume or Adam Ferguson. The immanent problem, aggravated by Mossel's practices, of the contradictions between free trade and the state power was the subject of Pieter de la Court's famous treatise, The Interest of Holland (1662; numerous reprints; a new English translation appeared in 1746). It became one of the most influential economic textbooks in the 17 th and 18 th centuries. ${ }^{9}$ There is no proof that Mossel or anyone else in Batavia ever read or discussed this "Dutch" economic treatise.

The very few texts Mossel wrote in his life demonstrate an excessive petty bourgeois bookkeeper's mind like the notorious Reglement ter Beteugeling van Pracht en Praal (Ordinance to Bridle Pomp and Splendor, 1754): more than 120 rules related to the proper design of houses, the use and shape of walking sticks, buttonholes and shoe-buckles. It was published by a man who loved excessive splendor during his inauguration as Governor-General, drink-parties and-without doubt-his own lavish funeral.

His next mistake concerned Mossel's alleged understanding of the British commercial interest. This must be a chutzpah: it is Governor-

7 The only source Blussé mentions to support his opinion is an unsigned manuscript from September 1794, which is, therefore, written 33 years after Mossel's death. At that time the VOC had already collapsed, and Mossel's many heirs and co-profiteers had, of course, no interest in being blamed for this.

8 It is a similar opinion to the one made by a well-known judge in 1923, who wrote in a handbook about "East Indies Law of the State": "The amphioen society and later the antiopium society agitated against the smuggling and against the lease-system.' J. Slingenberg, p. 91.

9 C. Boxer (1977) starts his book with a picture and discussion of De La Court's ideas. 
General Mossel, who started a war against the English in Bengal and Coromandel in 1759 (after Plassey) without even the faintest knowledge about warfare on sea and land or the ability to organize it. This war was not only a military disaster, it was a serious commercial one as well: from this moment on, the English definitely took over the position of leading power in Asia. The Dutch, largely dependent as they were on Bengal textiles, opium and saltpetre, had to pay a dear price as a customer of the British. It took the complete destruction of the VOC and the occupation of Java by the English before the Dutch realized that they had to change their colonial policy drastically (whether they could or did so will be discussed later).

But why do I call Mossel the first private opium dealer on a large scale? Blussé does not write anything about the activity with which Mossel created an innovation in world history, the establishment of the Amphioen or Opium Society in 1745. In every biography this is rightly stressed as Mossel's most remarkable activity. Let's first give a few biographical details.

Jacob Mossel was born in Enkhuizen to a humble reformed Protestant family. In the Dutch Golden Age, Enkhuizen was one of the important sea and commercial ports. His poor but rather fanatic father must have taught him how to chase after money; his mother, how to read and write, because she is apparently of impoverished but better standing. It must have been the effect of this education which Mossel demonstrated so exuberantly during the rest of his life: the nouveau riche syndrome of humble people becoming rich (he always showed his audience his "family crest", which impressed his colonial entourage, mostly of low descent like himself).

As was usual for poor boys, 15-year-old Jacob went to the East with a VOC ship, as an ordinary seaman for 8 guilders a month (1720). As soon as he arrived at the Cape of Good Hope, the young economist wrote his mother that

business is bad here, because the Spanish butter and soap are expensive ... Mutton, usually costing two penny (stuiver) is here 10 to 12 pennies. I do not buy it, because in Batavia prices will be lower. ${ }^{10}$

It was discovered that young Mossel could write, an exceptional ability in the VOC, which gave him a clear advantage. A year later he had a job on the Coromandel coast well known for its Dutch slave and textile trade where

10 Quoted by S. Duys. When not indicated otherwise, quotations are from this author, who had to write the most favorable text about Mossel for tourists! 
he immediately acquainted oneself with the illegal traffic in the VOC's monopoly articles, known as private ... smuggler's trade ... But while high and low smuggled, the big money was only reserved for the elite. ${ }^{11}$

Apparently, the boy decided to become part of this elite: four years later he already occupied the strategically important position of bookkeeper (for 30 guilders a month + bonus of 400-76o guilders a year). Again four years later, he married the 14-year-old daughter of the VOC governor of the Coromandel coast. This gave him a larger monthly income, a better status (main slave trader as 'senior merchant' or head of the administration) and successor to his father-in-law. Boxer informs us how the European servants of the EIC and VOC often worked closely together

to cheat their respective employers, often also in cooperation with French, Portuguese and Indian accomplices ... a cooperation ... in private trade and smuggling. ${ }^{12}$

Mossel is explicitly mentioned as one of those types. Even for Boxer's sober-minded judgments, he is quite aggressive against those Dutch historians who trumpet the praises of peoples like Mossel, Van der Parra or the VOC performance in general.

When Mossel departed for Batavia, he was already a rich man in VOC terms (with 32,200 guilders saved, which is about one million euros in present value) 'which he could not have gained with his official salary and bonus'. That was not unusual among the elite. A governor of a far-distant VOC post like Mossel officially earned 2,400 guilders a year, but with illicit additional income, one could increase this with some luck and brutality to 100,000 guilders. It was the "official" mentality of the VOC elite to make 'silent profits'.

Still, there were always exceptionally greedy persons like, for instance, Governor-General Van Hoorn, who left Batavia in 1709 with a fortune of 10 million guilders, a "Bill Gates Fortune" in present value. Gaastra called him capable in the meaning of "not corrupt"!

Mossel was also brilliant at accumulating capital. Once back in Batavia (1742) he soon entered the highest ranks in the VOC and could now easily

11 The Dutch have more names for illicit trade, very well known to the VOC people like 'mors-, sluik-, smokkel- or privé-' trade. The last word is, of course, strange, but understandable within the VOC jargon in which everything outside VOC command was illicit, including private trade. Mossel himself wrote that in this VOC trade, people acted 'too extreme and rude beyond any imagination'. As a slave trader he was involved in the most inhuman business of the VOC, as people already knew at that time.

12 C. Boxer (1977), p. 75, see also p. 8 o. 
see what was the biggest money source in the colony. It was not difficult for him with his bookkeeper's mind and slave trader's experience to make this fixed VOC capital current so that he could fill his own pocket, once he had the key of the treasury.

In November 1745 a ten-year contract (octroy) was drawn up between the Dutch colonial state/VOC and a group of private people gathered in a club. ${ }^{13}$ For the State/VOC the import part of its opium monopoly remained as it was, but the distribution part was taken over by this AS. The government hoped to stimulate the sale of this already lucrative business and to counteract smuggling by VOC officials, English merchants and others.

It was called a "reorganization of the trade" to produce more profit for the state: nobody was against this. It was also called "privatization": nobody was against that, because the most important people in the colony were invited to participate and accepted becoming profiteers in the game; it was aimed at "avoiding smuggling": nobody was against it, because every participant at this level had the same or similar experiences and wanted to eliminate his competitors. The exclusive object of the trade was opium: everybody knew how easy it was to smuggle this product and how much profit could be gained with it after a century of VOC infiltration.

The invited profiteers of the new activity were only a few rich and influential people, bureaucrats and 'free burghers', who could distribute among each other only 300 very expensive shares of nearly 5000 guilders each (two years of salary for a governor in a VOC region). In their official functions these persons were the leaders of the VOC, and they agreed to offer themselves the most lucrative opium distribution monopoly.

The new club was called the Amphioen Society (AS). Of the 300 shareholders, six did some work as new opium ships arrived from Bengal twice a year. In two meetings the few attendants exchanged part of the VOC monopoly with the AS for a price; largely a movement from one hand to the other. Another two meetings, the auctions, were held between some AS members and the former VOC opium farmers: theoretically, they could have been attended by about 106 AS persons; practically, it may have been a quick meeting between a few representatives of the farmers and a few AS members. Later, two AS members did some administrative work: who had paid cash, who used credit; the transmission of the interests to the

${ }^{13}$ For the general data of the AS see R. Manurung, F. Gaastra (2006), E. Vanvugt (1995), p. 106-116. 
shareholders. All in all, a few days "hard labor" per year for a fantastic salary.

The AS was, therefore, nothing but an intermediary or "middleman" between the VOC and the opium farmers. It reserved the most promising source of money for itself by emancipating it from the rest of the complicated VOC business. In return, the members promised to buy from the VOC a fixed amount of 1200 chests every year (with some additional conditions). The VOC-colonial state kept the import monopoly and remained responsible for the military security in the whole archipelago: it was, therefore, a construction which gave only advantages to the participants and the costs to the "taxpayer". That is to say: the navy was instructed to chase the "smugglers", the main competitors of the AS participants.

The first director of this purely narco-military AS became Jacob Mossel. He started out by gaving himself a salary of 7,200 guilders a year, which was nearly three times as much as a comparable VOC official could earn in Amsterdam. This brilliant salary, however, was peanuts compared to the forty shares he took for himself. To buy these shares, Mossel must have "earned" about 160,000 guilders in two years (since he arrived in Batavia). Even from a VOC perspective, this is a most astonishing achievement. ${ }^{14}$ The only source of it could have been opium through smuggling or administrative corruption. The details are difficult to prove, but the following reconstruction seems to be a reasonable compensation.

Officially, the plan for the AS came from the ailing Governor-General Van Imhoff himself. Of course, a Governor-General in a colony is always

14 The value of the shares was 192, ooo guilders, and he came to Batavia with 32,000 guilders in his pockets two years earlier. F. Gaastra (2006), p. 104 for the first amount. Let us look at the usual incomes at the time. Around 1700 the Netherlands had around $10-20 \%$ unemployed, beggars, etc. Next came the soldiers, sailors, unskilled laborers, etc. with an income seldom higher than 200 guilders a year. Then there was the petty bourgeoisie (skilled laborers, small shopkeepers, etc.) with a yearly income of between 200 and 400 guilders; a middle class of lower officers, clergymen, small entrepreneurs, etc. had an income of at most 1200 guilders; the upper bourgeoisie (higher officers, large merchants, rentiers, etc.) were well paid with double that amount; finally, there was the $3-4 \%$ of the patriarchy (aristocrats, highest government bureaucrats, etc.) with "everything above the last amount". See H. Schipper, p. $110 \mathrm{ff}$. In the 18th-century the level of the real wages of the petty bourgeoisie was about 10\% higher until 1730, but after that year it decreased quickly and substantially to the lowest level in 200 years. See J. de Vries, A. v.d. Woude, p. 722. From the many data mentioned in Idem, p. 647-689, about the 18th-century, one cannot see large differences from those mentioned above: $75 \%$ of the Amsterdam shopkeepers had less than 1200; only $2 \%$ earned more than 3000 guilders in a year. The largest incomes were earned by the highest government bureaucrats: the mayor and aldermen of Amsterdam with about 7000 guilders per year in 1742. This shows how exceptional the AS opium remunerations were! 
the cleverest person, but he was clearly not the boss. A Jacob Cool (the 'Court Jew of Van Imhoff), who also became a member of the AS board and who was originally the proud possessor of thirty shares, was urged to leave ten of them to his 'favorites'. The result of this shuffle was that Mossel had twice as many shares as anybody else, including Van Imhoff.

As compensation, the latter was nominated "president of the AS" (opper-directeur). There must have been specific reasons for this remarkable behavior of Mossel's colleagues: throwing mud and malice at each other was second nature in this rich and corrupt milieu. The most reasonable explanation was that Jacob Mossel was in a position to bribe them all and to buy their silence with the promised profits. A basis for this hypothesis would be a specific relationship with the opium producers in Bengal (doubtless, he had a profound knowledge about the Bengal opium trade) or specific knowledge about smuggling practices, etc.

There is another indirect indication about Mossel's position: after he came from India to Batavia, the opium profits suddenly trebled from 512,000 to $1,415,00$ guilders. They remained exceptionally high for the next few years, around one million guilders, while the average was not more than half of that (see Appendix 3). It must have been this circumstance which triggered the establishment of the AS, the position of newcomer Mossel as its Director, and Mossel's remarkable sudden wealth. All this made Jacob Mossel the first opium dealer on the largest possible scale at the time. Until his death in 1761 , he remained the unchallenged dealer with opium revenues on top of his other lucrative functions.

Although this trade was confined to the inter-Asian realm, Mossel and his AS received fantastic support from the Netherlands as well. Most shareholders lived there. A remarkable participant in this opium game was the royal family, the stadholder William IV himself. This Prince of Orange was invited to became a shareholder with thirty shares in 1748 . He was promised that in 1755 he would be 200,000 guilders richer, without having to do anything, when the octroy of the Amphioen Society expired. Every time the octroy was renewed, this "stadholder" and his successor, William V, would receive an enormous amount of opium money (e.g. $1,187,280$ guilders in 1795). ${ }^{15}$ All shareholders together pocketed in total about 13 million guilders; at the time it was a fabulous amount of money comparable to a present value of about a billion guilders. ${ }^{16}$

15 F. Gaastra (2006), p. 105, 106.

16 The details about these shareholders and most of his text were copied by Gaastra from an unpublished script from I. Mens (1987). Gaastra never altered his favorable opinion about Mossel. 


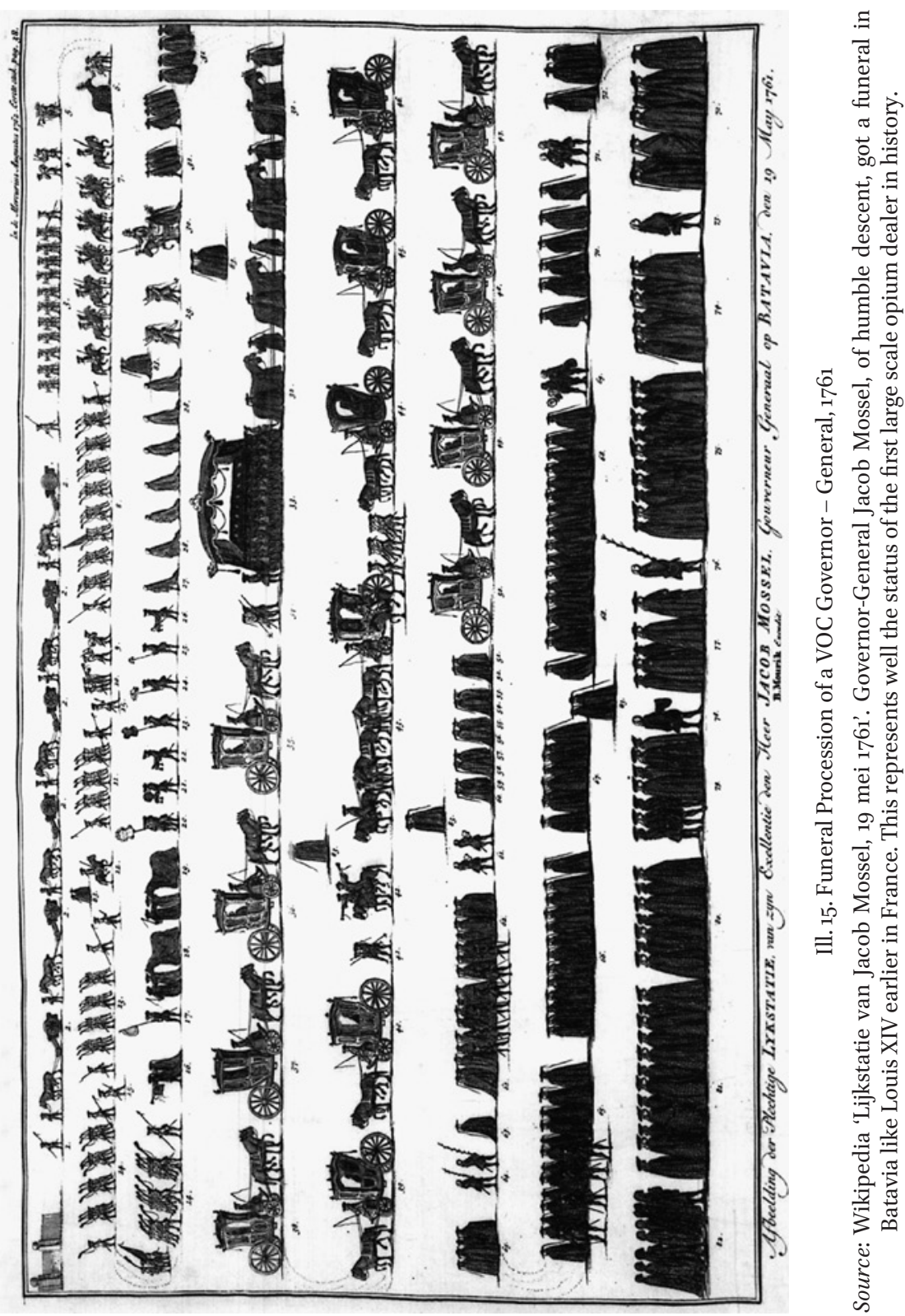


Last but not least, Mossel also contributed to the final decline of the VOC by what he did well, in hindsight. In November $175^{2}$ he sent a report to the VOC Directors in Amsterdam in which he complained about the marked decline of the company's trade with Asia. ${ }^{17}$ The Dutch had a representative in Canton, and enormous profits could be made here with new attention and investments ... in the tea trade.

As detailed in section ch. 6, this was the very product "in cooperation" with opium which, indeed, brought the British Empire to the summit of its power, wealth and extension. Mossel rightly stipulated that the VOC had a marked advantage in this Chinese trade, since it had products available for the Chinese which they liked: tin, pepper, cotton, wax, spices and other goods. Their competitors had to pay for tea with precious metals or opium.

The Directors reacted, however, with a very stupid plan (in hindsight): they decided to bypass Batavia and the VOC, while establishing a completely new organization only directed to the trade with Canton: they created their own competitor and demonstrated, in fact, that for them the VOC (including Jacob Mossel) was as dead as a doornail.

\section{The AS Performance}

That is the personal side of the AS story. ${ }^{18}$ A more interesting aspect is the opium performance of the AS compared with the normal VOC opium business. What people like the "President" of the AS thought of it is given in the following symptomatic (and nonsensical) reasoning:

The Society receives the amphioen [from the VOC] for $45^{\circ}$ [rixdollars per chest] and sells this for $55^{\circ}$... It is certain that nobody can sell it cheaper ...9; except, of course, the VOC!

In Appendix 2 we have given the comparative data over a period of 24 years. This comparison does not fit in the sense that the "VOC period" is chronologically earlier than the "AS period"; wars or crop failures could

17 For the following see L. Blussé (2008), p. 58 ff.

18 Appendix 2 to F. Gaastra (2006), p. $113 \mathrm{ff}$. provides Mens' list of all shareholders in 1801 with incorrect sums (not the indicated 300 but about four less). Only 56 of the shares remained in Batavia and most of the rest in the Netherlands, dispersed over many places and institutions like an orphanage with not fewer than 22 shares and even a pawn-bank with 5 .

19 GM, XI, p. 635 . 
have taken their toll, which makes historical comparison difficult. But the periods seem to be long enough to make the statistically viable conclusion that the totals of both performances generally did not differ much: the profits per chest were nearly the same (540 and 560 guilders), the profits per pound weight were nearly the same ( 3.55 and 3.85 guilders), etc.

The next conclusion to be drawn from the table is that the AS on average did not fulfill its promise always to buy 1200 chests from the VOC. All kinds of excuses were given for this (see below), but the table also shows how remarkable regularities occur (see period 1755-1761). It seems obvious that corrupt people like the AS members manipulated the administration; in the VOC table this kind of regularity does not appear.

From other sources comes additional information about those "irregular years" and complaints. Immediately at the end of 1746 , the impatience of the greedy is heard in the AS complaints: the profit may be $158 \%$, but in Bengal the purchasing price must be lowered, so that the profit can become 450 rixdollars per chest or $200 \%{ }^{20}$ Ten years later 1200 chests were imported from Patna for the price of 1,296,000 guilders (fl. 1080 per chest). That was apparently 200 chests too much for the AS. It requested the government to be exempt from this obligation, 'but the Government had another view about it, whereupon the AS asked to send 100 chests to the West of India, which was agreed with the consent of Bengal'.21

Three years later there was a problem with the quantity per chest: in most of the delivery, this was about 70 kilogram too little. The government decided to deliver the shortages to the AS, which was a good subvention. ${ }^{22}$ In April 1761 four ships had come from Bengal with the usual 1200 chests of opium. However, the first three carried not more than 293 chests and the last another hundred, while the price per chest was increased by nearly 400 guilders per chest to about 1500. Reason: the indigenous merchant stated that it was impossible to deliver 1200 chests because the constant movement of troops had destroyed a large part of the poppy fields. ${ }^{23}$

Above it was stated that the AS was an intermediary club: profits on two sides, without great risks. The effects of its mere existence were many and serious. Contrary to the long quotation at the beginning of this chap-

\footnotetext{
20 GM, XI, p. 464; same complaint Idem, p. 634.

21 GM, XIII, p. 104.

22 Idem, p. 470.

23 Idem, p. 621.
} 
ter, the VOC lost the AS's substantial profits. Next, this means that the price of the product for farmers of the AS was increased by the profits and costs of the AS members and interests of the shareholders. The VOC monopoly price was by definition lower than the AS monopoly price. This led to the opium farmers becoming more motivated to increase the number of their clients; opium being distributed more in society; and more addicts.

However, there was another reaction. The AS was established under the pretext of avoiding "smuggling", but the greater the price increase, the sooner the opium farmers would look for alternative suppliers, i.e. "smugglers". Instead of preventing smuggling, the AS must actually have increased the chances for "smuggling". The complaint one reads time and again in the Generale Missiven is that the English smugglers from Bencoolen (west coast of Sumatra) were becoming increasingly more active. This "smuggling" represents the workings of a free competitive market (to be counteracted by all means).

Another serious effect of the AS performance was that VOC officials not involved in the AS or who did not belong to the "AS club" felt free to conduct their own opium business. De Haan gives several examples including the fancy prices they made per chest of opium. ${ }^{24}$

These effects of the monopoly opium trade, as emancipated from the rest of the VOC business, contributed to the decline of the VOC. There were more factors involved. One of the means to obtain as much profit as possible was to manipulate the quality of the product. A few examples will suffice.

Van Imhoff wrote to Amsterdam (31 December 1746) that private opium dealers are not allowed to trade without a Company pass. And to avoid smuggling, 'one ordered from Bengal 300 chests of amphioen second quality, so that indigenous people can get cheap opium not only from smugglers but also from the Amphioen Society...' 25

Trouble occurred between the Company and AS as well. At the end of 1751 it was reported to Amsterdam that business had not been good that year due to a lack of pepper and opium. In Hughly 925 chests were pur-

24 F. de Haan, vol. 4, p. 21 ff. the opium business of the "Regentschappen", persons like Nic. Engelhard, etc. with their shameless business morality and exorbitant profits. These persons continued to serve under the new conditions when the AS and the VOC had perished.

25 GM, XI, p. 396. The AS was even prepared to corrupt its own position to buy opium from smugglers. See Idem, p. 333 . 
chased, but 263 of them were considered of bad quality in Batavia and as good in India:

... the VOC representative [opperhoofd] in Patna, Drabbe, has now to pay a fine of fifteen rixdollars per chest, but the Amphioen Society has already sold them for good quality because of the shortage there was a strong motivation to buy. ${ }^{26} \mathrm{~A}$ year later the VOC obtained again a hundred chests of 'second quality' but sold them to the AS for 432 guilders a chest, but the AS refuses: 'we cannot sell them and want to pay next time not more than 360 ...' which is the Malacca price. This price is so low, because the English are very active in smuggling.. ${ }^{27}$

In this way the AS introduced the policy of distributing bad quality as good, which has the same effect as in another political economy: bad money drives out good money. It is a game which was played on a much larger scale a bit later in India by "smugglers in the view of the EIC", centered in Malwa (Bombay). They were struggling against the monopoly of the Bengal-British opium, until the British also captured this part of India, with the effect that from that moment on, the British themselves traded with different qualities. The effect of doing this was to enlarge the opium market because poorer consumers can buy cheaper stuff. This is bad for their health, but dealers were never concerned with that, on the contrary.

For outsiders, the connections between the AS and the VOC were very obvious. The practical status of the AS can be indicated by the following examples.

To exploit its opium resource to the utmost, the AS introduced a lease on smoking prepared opium (madat) in districts outside Batavia at the end of 1746 . However, this turned out to be a miscalculation: the opium income decreased, and corruption increased. Half a year later, this lease was cancelled: '... the opium leaser has to pay four month lease, half to the Company and half to the Amphioen Society'. ${ }^{28}$

In $175^{0}$ the bosses in Amsterdam were thanked for accepting the continuation of the AS for another 25 years, because the opium trade wa 'the most important' for their business: the AS had bought 1300 chests and that gave the VOC an 'income of between eight and nine hundred thousand

26 GM, XII, p. 174.

27 GM, XII, p. 271, see also Idem, p. 337. The differentiation in several qualities (and prices) of opium is, for instance in 1752/53: of the 1265 chests 998 were 'Behaarse' (617 of which were sold in Patna and the rest in Hughly), while 267 chesst were bad quality from 'Pourannias and Baggelpourian'. See also Idem, p. 504 and GM, XI, p. 407, 408.

28 GM, XI, p. 598. 
guilders'. This was about $40 \%$ of all trade in that year. ${ }^{29}$ Nine years later (in 1759/6o) the delivery of a thousand chests of opium amounted to half of the value of the total delivery of goods (2,125,986 guilders) ${ }^{30}$ As shown in Appendix 2 they were exceptionally good years.

The AS status is well circumscribed with a text demonstrating how it fits into the usual monopoly game. It concerns violent quarrels between the VOC and the Sultan of Jambi (east coast of Sumatra) in 1760 and the Dutch blockade of all his ports:

If the Sultan responds adequately to the just demand of the Company, then the passage of vessels with a pass is freed. Ships which carry spices and opium without the mark of the Company or the Amphioen Society, however, must be confiscated and brought to Batavia without damage, whatever the Sultan may do with our demand. Captains of ships from foreign nations who intend to trade with Djambi must be warned not to do this, emphasizing the exclusive rights of the Company. If necessary, this right will be defended by force in order to avoid disadvantage for the Company's trade ....

In a secret letter accompanying this instruction, the Dutch military are warned not to be cheated by 'those deceitful natives while their own merchants must be saved by threatening the natives with punishments ...' The same page of the Generale Missiven reports about the Company's negotiations with a Siamese ruler for the delivery of forty catty of silver. The representative of the VOC is urged by Governor-General Mossel to threaten this ruler as well. Why?

How reasonable and affable these people may be treated [by us], it appears as crystal clear that this nation abandons itself to unsatiable greed while the possession of only a few goods is more important to them than their honor and decent name, yes, even more than the need and wealth of their countries. ${ }^{32}$

It seems a good formulation to demonstrate how the perpetrators, represented here by the most high-ranked slave and opium trader, are always ready to accuse their victims of their own mistakes to legitimate their repression. This way of silencing their own conscience had the most farreaching and lethal consequences, as the following story reveals.

\footnotetext{
29 GM, XII, p. 77.

30 GM, XIII, p. 609.

31 GM, XIII, p. 528.

32 GM, XIII, p. $5^{28 .}$
} 